\title{
ZUIKER ONDERNEMING DI KABUPATEN KLATEN1870-1942: PENGARUHNYA DALAM BIDANG SOSIAL DAN EKONOMI
}

\author{
Ririn Darini, Dyah Ayu Anggraheni Ikaningtyas, Mudji Hartono \\ Email: ririn_darini@uny.ac.id
}

\begin{abstract}
This research wanted to see the early entry of investors-private financiers to the Dutch East Indies, which has contributed to the entry of many private companies in Indonesia today. Agrarische Wet (1870) was an early milestone in the entry of foreign investors into the Dutch East Indies. This foreign investor is the owner of private companies in the Dutch East Indies, including in Klaten. The companies led to the construction of transportation facilities, trains; criminality; absorption of community labor and also use monetization or circulation of money in native kalangang.
\end{abstract}

\begin{abstract}
Abstrak
Penelitian ini ingin melihat awal masuknya pemodal-pemodal swasta ke HindiaBelanda, yang tentunya juga memiliki andil dengan masuknya banyak perusahaan swasta di Indonesia saat ini. Agrarische Wet (1870) merupakan tonggak awal masuknya pemodal-pemodal asing ke Hindia-Belanda. Pemodal asing ini adalah pemilik perusahaan-perusahaan swasta di Hindia-Belanda, termasuk di Klaten. Pembukaan perusahaan-perusahaan perkebunan menyebabkan pembangunan sarana transportasi, kereta api; adanya kriminalitas; ppenyerapan tenaga kerja masyarakat pribumi dan juga mengakibatkan adanya monetisasi atau peredaran uang di kalangang pribumi.
\end{abstract}

\section{A. Latar Belakang}

Pada tahun 1870 Undang-Undang Gula menyatakan berakhirnya Sistem Tanam Paksa, sedangkan Undang-Undang Agraria dan Dekrit Agraria memudahkan hibah tanah jangka panjang bagi perusahaan Eropa. ${ }^{1}$ Tahun 1870 merupakan tonggak yang sangat penting bagi sejarah agraria karena sejak itulah para pemodal asing dari Eropa mulai memasuki kawasan Hindia Belanda secara besar-besaran. Dengan dikeluarkannya UU Agraria 1870 tersebut, perkebunan partikelir berkembang di Indonesia, terutama di Jawa dan Sumatera. Dalam usaha

${ }^{1}$ Boomgard, Peter, Anak Jajahan Belanda: Sejarrah Sosial dan Ekonomi Jawa 1795-1880, (Jakarta: Djambatan, 2004), hlm. 64. 
perkebunan partikelir, para pengusaha dapat memperoleh tanah perkebunan melalui tiga cara, yaitu erfpacht, sewa, dan konsesi. ${ }^{2}$

Pembukaan perusahaan-perusahaan perkebunan oleh swasta asing di Hindia Belanda berdampak pada penyerapan tenaga kerja masyarakat pribumi. Masyarakat Jawa Tengah termasuk Klaten banyak yang bekerja di sektor perkebunan seperti perkebunan tebu, tembakau, dan nila. Hal demikian tidak selaras dengan etos masyarakat sekitar daerah perkebunan di Sumatera Timur. Banyak di antara masyarakat Sumatra Timur yang tidak mau bekerja di sektor perkebunan milik asing. Hal tersebut mengakibatkan pemerintah mengeluarkan kebijakan untuk melakukan transmigrasi bagi masyarakat Jawa ke Sumatera, untuk bekerja di sektor perkebunan milik swasta.

Dengan dibukanya perusahaan perkebunan di beberapa daerah di Jawa, termasuk Klaten, hal ini berakibat atau memberikan dampak dalam bidang social dan ekonomi bagi masyarakat, khususnya petani. Penelitian ini ingin melihat bagaimana dampak maraknya perusahaan swasta bagi masyarakat pribumi dan apa saja pengaruh langsung yang dapat dihadapi oleh masyarakat Klaten.

\section{B. Metode Penelitian}

Penelitian ini adalah penelitian historis yang tentunya akan menggunakan metodologi sejarah. Pencarian sumber dilakukan dengan mencari literatureliteratur yang berkaitan dengan penelitian. setelah literature diperoleh, maka akan dilakukan verifikasi dan pengecekkan kebenaran sumber atau literature yang ditemukan. Setelah itu sumber-sumber diintepretasikan. Dalam langkah ke tiga ini, analisis dan imagenasi peneliti diperlukan untuk membangun kembali peristiwa masa lampau yang telah berserakan. Setelah sumber-sumber dianalisis, langkah terakhir adalah historiografi atau penulisan.

\section{Pembahasa}

${ }^{2}$ Mubyarto, Tanah dan Tenaga Kerja Perkebunan: Kajian Sosial Ekonomi, (Yogyakarta: Aditya Media, 1992), hlm. 38. 
Adanya kebijakan yang dilakukan oleh Pemerintah Hindia-Belanda dalam sistem onderneming dan tanah partikelir di Hindia-Belanda menjadi sebuah babak baru dalam sejarah social dan ekonomi perkebunan di Indonesia. Perluasan di bidang perkebunan era tersebut telah mencapai keberhasilan dan pencapaian yang besar terhadap perekonomian Pemerintah Hindia-Belanda. Hal tersebut terjadi pada industri gula di Kabupaten Klaten, sehingga menimbulkan ungkapan, bahwa "Industri gula adalah gabus tempat Hindia-Belanda mengapung". 3 Namun, di balik keberhasilan yang telah dicapai oleh Pemerintah Hindia-Belanda dalam bidang perkebunan tebu, juga telah berpengaruh kepada masyarakat yang tidak hanya terjadi pada sektor sosial, sekonomi dan perkembangan penduduk atau demografi.

\section{A. Dampak Sosial}

Sejak awal abad ke-20, sebagian besar wilayah Klaten merupakan wilayah perusahaan perkebunan, yaitu: di kawedanan Klaten terdapat 6 buah pabrik gula, kawedanan Gondangwinangun 6 buah, kawedanan Pedan terdapat 1 buah pabrik gula serta sisanya di daerah lainnya. ${ }^{4} 25$ sampai 40 persen wilayah merupakan area perkebunan, ${ }^{5}$ yang mana sebagian besar diperoleh dengan cara menyewa dari para petani.

Perjanjian persewaan tanah bagi perusahaan perkebuan dibuat dalam sebuah akte yang diketahui oleh bupati. Ketentuan-ketentuan perjanjian sewa tanah yang harus ditaati di antaranya: (1) perjanjian persewaan tanah dengan desa atau pemegang hak tanah lungguh, jangka waktunya adalah $12 \frac{1}{2}$ tahun bagi tanah sawah, sedang bagi tanah tegalan atau pituwas, jangka waktunya adalah 30 tahun. $^{6}$

${ }^{3}$ Mubyarto Daryanti, Gula:Kajian Sosial-Ekonomi, (Yogyakarta: Aditya Media, 1991),hlm. 11.

${ }^{4}$ Soegijanto Padmo, Landreform dan Gerakan Protes Petani Klaten 19591965, (Yogyakarta: Media Pressindo, 2000), hlm. 54.

${ }^{5}$ Geertz, Cliford, Agrcultural Involution: The Process of Ecological Change in Indoneia, (Barkeley: TP, 1966), hlm. 74.

${ }^{6}$ Suhartono, Apanage dan Bekel: Perubahan Sosial di Pedesaan Surakarta (1830-1920), (Yogyakarta: Tiara Wacana, 1991), hlm. 111. 
Keberadaan perusahaan-perusahaan swasta membawa dampak bagi kehidupan sosial masyarakat Klaten, diantaranya:.

\section{Transportasi Umum}

Pada mulanya masyarakat mengangkut hasil panen menggunakan transportasi tradisional, misalnya cikar dan gerobak yang ditarik menggunakan tenaga kuda dan sapi. Kemudian ketika maraknya perusahaan dan perkebunan, maka dibuatlah transportasi yang mempermudah pengangkutan barang-barang hasil perkebunan. Jalan-jalan yang rusak diperbaiki. Selain itu, pertengahan abad ke 19, rel kereta api/ jalur kereta api mulai dibuat di Hindia Belanda.

Permintaan perusahaan-perusahaan untuk diadakan transportasi kereta api sebagai alat transportasi lebih efisien daripada alat transportasi yang sudah ada, pada tahun 1862, perusahaan swasta yang bernama Nederlandsch-Indische Spoorweg Maatschappij (NISM), memprakarsai pembangunan rel kereta api. ${ }^{7}$

Pada 2 Maret 1872, jalur Semarang-Vorstenlanden (Solo-Yogyakarta) sejauh $58 \mathrm{~km}$, diresmikan. ${ }^{8}$ Pasa awalnya jalur ini dibangun untuk mengangku hasil perkebunan tebu, namun kemudian juga mengangkut penumpang manusia. Kereta api menyebabkan pengangkutan hasil perkebunan lebih efektif dan efisien. Pada mulanya, jumlah gula dari pabrik-pabrik gula yang ada di Yogyakarta dan Surakarta yang diangkut melalui jalur tersebut sampai pelabuhan semarang berjumlah 13. 773 ton gula; kemudian mengalami peningkatan tahun 1883 menjadi 55. 618 ton gula; dan tahun 1893 sebanyak 71.671 ton gula. ${ }^{9}$

Transportasi kereta api, selain digunakan sebagai alat angkut dan distribusi hasil perkebunan, juga digunakan untuk mobilitas masyarakat, baik bagi golongan Eropa maupun Bumiputra. Tarif kereta api juga berbeda-beda tergantung jenis kereta api. Terdapat tiga jenis kereta api, yaitu kelas satu, kelas dua, kelas tiga dan kelas empat. Kereta kelas satu dan dua yang dikhisiskan bagi penumpang Eropa, memiliki tarif sembilan dan enam sen per kilometer, sementara hlm. 172.

${ }^{7}$ Kunto Wibisono, dkk, Kereta Malam, (Yogyakarta: Gong Grafis, 2015), ${ }^{8}$ Ibid.,hlm. 121.

${ }^{9}$ Suhartono,1991, op.cit., hlm. 132. 
yang kelas tiga dan empat, kelas pribumi, dua dan satu sen per kilometer untuk kelas 3 dan $4 .{ }^{10}$ Transportasi kereta dimanfaatkan oleh Bumiputra sebagai salah satu alternatif lain dalam menghemat waktu ke tempat kerja dengan jarak kurang lebih $10 \mathrm{~km}$.Sambungan jalur utama Semarang-Vorstenlande (Solo-Yogyakarta) nyatanya telah membawa kemudahan bagi kehidupan sosial masyarakat, khususnya masyarakat daerah sekitar perkebunan di wilayah Klaten.

\section{Kriminalitas}

Di Karesidenan Surakarta, termasuk Klaten di dalamnya terdapat perbedaan antara pengorganisasian antara perkebunan tembakau dan perkebunan tebu. Pada abad ke-20, di perkebunan tembakau tidak pernah ada laporan tentang munculnya protes oleh para petani, berbeda halnya dengan yang terjadi di perkebunan tebu. Petani di areal tebu pada saat menunggu musim tebang yang memakan waktu selama delapan bulan harus mencari sumber matapencaharian lain sendiri. Keadaan demikian dirasa sangat sulit bagi sebagian besar petani. Mereka pada umumnya tidak memiliki modal dan keterampilan melakukan kegiatan di luar sektor pertanian, sehingga mengakibatkan munculnya tindak kriminal yang tinggi di areal perkebunan. ${ }^{11}$

Perkebunan tebu sebagai komoditas utama pemerintah kolonial dengan keuntungan besar, nyatanya tidak demikian bagi pribumi. Keadaan sosial masyarakat di wilayah Vostenlanden termasuk di dalamnya adalah Kabupaten Klaten selama kejayaan perusahaan gula digambarkan sangat buruk. Para petani di pekebunan tebu dan indigo harus menyerahkan tanahnya kepada pabrik selama 15 bulan, yang mana tenaga petani dan istri serta anaknya terserap ke dalam kegiatan perkebunan tebu selama 5-6 bulan, setelah itu tidak ada kegiatan lain karena selama musim tebang hanya dikerjakan oleh pria dewasa. ${ }^{12}$ Sementara itu, upah yang diterima oleh petani tebu tidak sebanding dengan yang mereka kerjakan.

${ }^{10}$ Ibid.,hlm. 133.

${ }^{11}$ Soegijanto Padmo, "Ekonomi Perkebunan dan Keresahan di Pedesaan Sebuah Survai Awal", Seminar Revolusi Kepahlawanan dan Pembangunan Bangsa, Oleh Museum Benteng Yogyakarta, 16 November 1994, hlm. 11.

${ }^{12}$ Ibid., hlm. 12. 
Masa tunggu dan upah yang kecil inilah yang menyebabkan terjadinya kriminalitas.

Pada tahun 1911, rata-rata upah petani tebu berkisar antara $f 0,20-0,30$ per hari, sedangkan harga beras di pasaran tahun tersebut mencapai $f \quad 10,53$ per kuintal. ${ }^{13}$ Keadaan yang terjadi dalam sektor agraris membuat para petani mengalami ketidakpuasan terhadap sistem kapitalisme. Bentuk ketidakpuasan dari kalangan Bumiputra adalah melakukan tindakan kriminalitas seperti perbanditan dan perkecuan.Kecu merupakan suatu kegiatan yang sangat dominan dan dalam tindakannya bersifat memaksa, meyiksa dan tidak segan-segan membunuh korban. $^{14}$

Aksi kecu di Kabupaten Klaten dan seluruh wilayah Keresidenan Surakarta telah terjadi sejak abad ke-19 dengan korbannya adalah orang-orang kaya seperti penguasa lokal atau bekel. Laporan Politik Surakarta tahun 1872 menyebutkan bahwa tahun 1872 telah terjadi 24 kali aksi pencurian oleh kawanan kecudi Keresidenan Surakarta. Pada tanggal 9-10 Januari 1875, telah terjadi tindakan pencurian yang dilakukan oleh kawanan kecudi rumah seorang Bekel Sumowedono di Desa Onggopatran, Klaten. ${ }^{15}$ Awal mulanya kawanan kecu berhasil menemukan kunci rumah korban yang disimpan di bawah tikar, kemudian membawa lari barang berharga yang berjumlah $f$ 1.117,50.Adanya peristiwa tersebut menyebabkan dua orang penjaga rumah, yakni Pak Tumpuk dan Pak Kamidin mengalami cedera karena adanya penyerangan berupa pukulan dari kawanan kecu. ${ }^{16}$

Pada tahun 1875 telah dilakukan pencegahan terhadap kawanan kecu, yaitu dengan mengadakan ronda malam dan diberikan penjagaan polisi di setiap

${ }^{13}$ Wasino, Kapitalisme Bumi Putra: Perubahan Masyarakat Mangkunegaran, (Yogyakarta: Lkis, 2008), hlm. 222.

${ }^{14}$ Suhartono, Bandit-Bandit Pedesaan di Jawa Studi Historis 1850-1942, (Yogyakarta: Aditya Media, 1995),hlm.143.

${ }^{15}$ Suhartono, "Kecu: Potret Peradaban Sosial di Vorstenlanden 18501900", Seminar Sejarah Lokal di Medan, oleh Departmene Pendidikan dan Kebuadayaan,Tanggal 17-20 September 1984, 12.

${ }^{16}$ Suhartono, Op.cip. 1995, hlm. 144. 
daerah atau desa guna memberantas gerombolan kecu. ${ }^{17}$ Namun, sampai dasawarsa abad ke-20 aktivitas kecu khususnya di wilayah Klaten masih menunjukkan frekuensi tinggi.Banyak masyarakat yang takut dengan kecu sehingga pada saat ada peristiwa perampokan penduduk lebih memilih untuk melarikan diri kemudian datang kembali setelah pelakunya pergi. ${ }^{18}$

Antara tahun 1885-1900, peristiwa pengkecuan di Kabupaten Klaten telah terjadi sebanyak 23 kasus dan merupakan jumlah terbanyak dibandingkan dengan daerah lain di seluruh Keresidenan Surakarta, yakni Boyolali berjumlah 13 kasus, Sragen berjumlah 16 kasus, Wonogiri berjumlah 8 kasus dan Surakarta berjumlah 15 kasus. Keadaan ini akibat dari kondisi wilayah Kabupaten Klaten yang mempunyai jenis tanah dan lahan yangsubur dan luas serta paling banyak dikembangkan untuk beberapa jenis perkebunan, salah satunya adalah tebu. ${ }^{19}$ Perluasan kecu yang mengancam ketentraman para landhuurder masih berlanjut hingga tahun 1923. Hal ini akibat dari munculnya organisasi politik modern yakni SI (Serikat Islam) yang mampu memberi wadah kepada masyarakat pedesaan. Namun, pada tahun berikutnya jumlah kasus akibat gerombolan kecu mengalami penurunan.

Sejak masa kolonial, masyarakat pedesaan telah dilanda pengaruh dari luar baik berupa pengaruh ekonomi uang, budaya akan pentingnya pendidikan, serta munculnya pengaruh politik pada awal abad ke-20. ${ }^{20}$ Pengaruh politik pada masyarakat daerah perkebunan muncul karena daerah perkebunan dianggap sebagai sumber ketidakadilan dan penderitaan bagi masyarakat. Gerakan protes petani yang muncul pada umumnya mempunyai ciri elementasi atau terpisahpisah, tanpa program, dan tidak mempunyai tujuan yang jelas.

\section{B. Dampak Ekonomi}

Pada tahun 1870Undang-Undang Gula menyatakan berakhirnya Sistem Tanam Paksa, sedangkan Undang-Undang Agraria dan Dekrit Agraria

${ }^{17}$ Ibid., hlm. 144.

${ }^{18}$ Wasino,op.cit., hlm. 324

${ }^{19} \mathrm{Ibid}$, hlm. 145-146 a

${ }^{20}$ Soegijanto Padmo, 1994, op.cit.,hlm. 14. 
memudahkan hibah tanah jangka panjang bagi perusahaan Eropa. ${ }^{21}$ Sejak dikeluarkannya UU Agraria 1870 tersebut, perkebunan partikelir berkembang di Indonesia, terutama di Jawa dan Sumatera. Dalam usaha perkebunan partikelir, para pengusaha dapat memperoleh tanah perkebunan melalui tiga cara, yaitu erfpacht, sewa, dan konsesi. ${ }^{22}$

Pembukaan perusahaan-perusahaan perkebunan oleh swasta asing di Hindia Belanda berdampak pada penyerapan tenaga kerja masyarakat pribumi. Masyarakat Jawa Tengah termasuk Klaten banyak yang bekerja di sektor perkebunan seperti perkebunan tebu, tembakau, dan nila. Hal demikian tidak selaras dengan etos masyarakat sekitar daerah perkebunan di Sumatera Timur. Banyak di antara masyarakat Sumatra Timur yang tidak mau bekerja di sektor perkebunan milik asing. Hal tersebut mengakibatkan pemerintah mengeluarkan kebijakan untuk melakukan transmigrasi bagi masyarakat Jawa ke Sumatera, untuk bekerja di sektor perkebunan milik swasta.

Dengan dibukanya perusahaan perkebunan di beberapa daerah di Jawa, termasuk Klaten, hal ini berakibat atau memberikan dampak dalam bidang ekonomi bagi masyarakat, khususnya petani. Selain menyerap tenaga kerja perkebunan, sistem sewa tanah juga terjadi di daerah sekitar perusahaan. Sistem pembayaran upah dan sewa dengan menggunakan uang telah terjadi di Klaten pada periode liberal. Namun, sebenarnya proses monetarisasi khususnya di Jawa Tengah diperkirakan telah terjadi sejak awal abad ke-19.

\section{Tenaga Kerja dan Upah}

Dampak ekonomi yang ditimbulkan dari keberadaan perusahaan perkebunan adalah terciptanya kesempatan kerja. Kesempatan kerja yangdimaksudkan diklasifikasikan menjadi dua, yaitu kegiatan produksi dan kegiatan pemrosesan hasil produksi. Hal tersebut merupakan akibat langsung yang melibatkan petani pemilik tanah yang digunakan untuk mengusahakan tanaman perkebunan,

\footnotetext{
${ }^{21}$ Boomgard, Peter, Anak Jajahan Belanda: Sejarrah Sosial dan Ekonomi Jawa 1795-1880, (Jakarta: Djambatan, 2004), hlm. 64.

${ }^{22}$ Mubyarto, Tanah dan Tenaga Kerja Perkebunan: Kajian Sosial Ekonomi, (Yogyakarta: Aditya Media, 1992), hlm. 38.
} 
khususnya tanaman semusim seperti tebu dan tembakau di Jawa, dan buruh yang direkrut dari daerah sekitarnya.

Pada tahun 1870-an dengan berkembangnya perkebunan tebu dan tembakau, permintaan tenaga kerja menjadi semakin meningkat.Tanpa adanya buruh atau tenaga kerja yang jumlahnya cukupdalam usaha perkebunan, usaha tersebut tidak dapat mendatangkan hasil yang memadai. Adapun tenaga kerja yang diperlukan bukanlah sembarang buruh, namun buruh yang dapat dibayar dengan gaji yang rendah. Dengan strategi yang demikian, usaha perkebunan dapat dikatakan sukses dalam artian ekonomi. ${ }^{23}$

Penanaman, pemeliharaan, pengangkutan, dan penyelesaian di pabrik-pabrik menyerap banyak tenaga kerja, bukan hanya tenaga kerja laki-laki, tetapi juga wanita dan anak-anak. Apabila dibandingkan denganperkebunan yang lain, perkebunan tebu ternyata lebih banyak menyerap tenaga kerja bebas. Pada tahun 1865, di Klaten mempekerjakan 6.523 orang. Pabrik gula Karanganom, Klaten memerlukan 2.148 orang atau sepertiga dari seluruh kebutuhan tenaga kerja di Klaten.Di Pabrik Gula Ceper telah mempekerjakan wanita dan anak-anak. Selain itu, pengerahan tenaga tambahan juga dilakukan dengan mendatangkan kuli harian dari distrik-distrik sekitar pabrik gula. $4^{24}$

Dalam pemberian upah bagi tenaga kerja,terdapat perbedaan penerimaan upah antara buruhyang umumnya orang Cina dengan buruh harian atau kuli glidhigan. Ambivalensi dalam penggunaan tenaga kerja merupakan bukti tambahan ekstraksi dari perusahaan perkebunan karena masih digunakannya kerja wajib. Kerja wajib di perkebunan tebu diperlukan 90 hari, sedangkan jika dihitung upah kerja sehari 30 sen, maka ekstraksnya berjumlah f 27. Keadaan demikian hampir seragam terjadi di beberapa pabrik gula.

Selain menimbulkan dampak langsung terhadap petani dan penduduk, adanya perusahaan perkebunan juga menimbulkan dapat tidak langsung dalam

${ }^{23}$ Sjafri Sairin, "Kiat Perburuhan pada Masa Kolonial: Kasus Perkebunan Sumatera Timur", dalam Perspektif Vol. 5 No. 1\&2, 1993.

24 Suhartono, Apanage dan Bekel: Perubahan Sosial di Pedesaan Surakarta 1830-1920(Yogyakarta: Tiara Wacana, 1991). hlm. 111. 
masyarakat, yaitu timbulnya usaha non pertanian. Pada umumnya, usaha non pertanian yang timbul berupa pemrosesan hasil pertanian seperti usaha pembuatan makanan serta perdagangan hasil pertanian.

Berbagai kelompok masyarakat di antaranya terlibat dalam kegiatan pengusahaan produksi industri perkebunan dengan intensitas yang berbeda. Dalam artian, setiap jenis tanaman yang ada di perkebunan, memiliki pengorganisasian yang berbeda-beda. Di perkebunan teh dan kopi, kegiatan pemanenan lebih banyak dilakukan oleh pekerja perempuan. Adapun untuk jenis tanaman keras seperti tebu, baik di Klaten maupun daerah lain beberapa jenis pekerjaan hanya bisa dilakukan oleh pekerja laki-laki, sedangkan pekerjaan yang lain dilakukan oleh pekerja perempuan.

Kesempatan kerja yang diciptakan oleh perusahaan perkebunan mampu mendatangkanpendapatan bagiparapetani dan keluarganya. Hal demikian juga mempengaruhi tingkat daya beli masyarakat di sekitar pabrik yang memunculkan berbagai jenis usaha seperti pemrosesan hasil pertanian, perdagangan hasil pertanian dan barang kebutuhan sehari-hari, serta perdagangan kecil lainnya. Oleh karena itu, dapat diketahui bahwa perusahaan perkebunan di daerah pedalaman menjadi pusat perekonomian dan pusat kegiatan ekonomi.

Bagi masyarakat Klaten, petani merasa dapat hidup berkecukupan dengan bermata pencaharian sebagai pekerja pabrik sertamenggantungkan upah yang diterima sebagai sumber penghidupannya. Para petani tersebut memberikan kesempatan menggarap tanah miliknya kepada buruh tani yang ada di desanya. Dengan demikian, perusahaan perkebunan membuka peluang ekonomi lebih banyak kepada berbagai kelompok yang ada di dalam masyarakat.

Meskipun keberadaan perusahaan perkebunanmampu menyerap tenaga kerja bagi masyarakat sekitar,jumlah pekerja tetap yang bekerja di perusahaanperusahaan khususnya di Klaten sangat sedikit. Adapun sebagai bukti adalah perkebunan Jungkare yang memiliki luas 4.543 bau plus dua pabrik gula 
mempekerjakan sekitar 2.148 orang pekerja. Perkebunan Delanggu seluas 1.686 bau hanya mempekerjakan 250 orang pekerja. $^{25}$

Pada masa feodalisme, pengerahan tenaga petani sering tidak mudah seperti apa yang diperkirakan oleh perusahaan perkebunan. ${ }^{26}$ Perusahaan perkebunan meminta bantuan bekelyang menguasai tenaga petani di setiap kebekelan untuk mendapatkan tenaga kerja. Bagi perusahaan tebu, bebrapa hari sebelum musim tebang atau panen, perusahaan memberikan uang panjer atau uang muka untuk mengikat para pekerja agar bekerja di perkebunannya. Jumlah uang panjer yang diberikan juga tidaksetara dengan pendapatan selama seminggu, bahkan sering kali telah dimanipulasi oleh para bekel. Demikian halnya dengan dengan mandormandor, mereka juga melakukan pemotongan upah milik para pekerja. ${ }^{27}$

Pada tahun 1917, di daerah Swapraja Surakarta telah terjadi perombakan struktur pertanahan atau yang dikenal dengan Reorganisasi Agraria. ${ }^{28}$ Salah satu esensinya adalah penghapusan tanah apanagedan sistem kebekelan. Penghapusan tanah apanagememudahkan proses komersialisasi tanah dan tenaga kerja guna meningkatkan produksi agro-industri. Mengenai tenaga kerja, petani bebas bekerja pada perusahaan perkebunan untuk mendapatkan upah. Liberalisasi tenaga kerja petani ini mendobrak sistem apanagekarena dalam sistem ini tanah dan tenaga kerja merupakan kesatuan. Liberalisasi tenaga kerja memberikan kebebasan petani untuk memilih majikan-majikannya. Lepasnya tenaga kerja dari ikatan feodal memungkinkan dimasukkannya dalam pasaran tenaga kerja. Walaupun demikian, tenaga kerja ini belum berarti meringankan ekstraksi petani karena petani tidak mempunyai "kekuatan menawar" sehingga nilai tukarnya tidak memadai atau terlalu rendah.

\section{Monetisasi}

25 Vincent J.H. Houben, Keraton dan Kompeni: Surakarta dan Yogyakarta, 1830-1870, (Yogyakarta: Bentang, 2002), hlm. 588.

${ }^{26}$ Suhartono, 1991,op.cit., hlm. 114.

${ }^{27} \mathrm{Ibid}$.

28 Soegijanto Padmo, Landreform dan Gerakan Protes Petani Klaten 1959-1965, (Yogyakarta: Media Pressindo, 2000), hlm. 30. 
Sejak tahun 1830, perekonomian masyarakat Jawa tidak hanya berdasarkan pada pertanian kecil-kecilan dengan sistem barter saja. Sebuah industri ekspor juga telah eksis pada periode sebelumnya. Sejak paruh kedua abad ke-18, ekonomi pedesaan di Jawa Tengah telah dipacu untuk kepentingan perdagangan ekspor. Kemudian, pada awal abad ke-19, praktik mengonversi pajak-pajak yang semula dalam bentuk baramg ke bentuk uang tunai sudah mulai dilakukan pada tingkat pertanian yang terendah. ${ }^{29}$ Contoh lain adalah pembayaran kepada para pekerja dengan sistem uang. Pendeknya, perekonomian agraris Jawa Tengah telah termonetiasi hingga tingkat tertentu sebelum tahun 1830.

Pada periode selanjutnya, sistem sewa tanah dilakukan dengan menggunakan sistem uang. Penyewaan tanah mempengaruhi jumlah uang yang beredar hingga mengalami peningkatan yang tajam. Hal tersebut merupakan akibat dari pembayaran-pembayaran tunai kepada para buruh harian yang bekerja di perusahaan-perusahaan perkebunan dan lainnya.

Pada awal tahun 1830, penyewaan tanah-tanah apanage untuk kepetingan areal perkebunan kian bertambah. Pada periode inilah penanaman tanaman tebu mengalami perkembangan. Selain tanaman tebu, komoditas ekspor yang lain seperti kopi, indigo, dan tembakau juga dikembangkan. Komoditas tersebut membawa keuntungan kepada pemerintah kolonial, namun mendatangkan kesengsaraan bagi para petani. ${ }^{30}$ Meskipun petani memperoleh upah kerja, namun upah tersebut digunakan untuk membayar pajak tanah dan menyesuaikan dengan pola konsumsi baru. Dalam hal ini, perusahaan perkebunan memiliki peranan penting dalam proses monetisasi karena dapat mengubah pola kehidupan masyarakat pedesaan.

Meskipun pada periode 1830-an berlaku Sistem Tanam Paksa di Hindia Belanda, di daerah Swapraja tidak diterapkan sistem tersebut. Namun, karena masih kuatnya ikatan feodal, sistem penyerahan wajib oleh para petani masih

\footnotetext{
${ }^{29}$ Houben, J.H, Vincent, op.cit., hlm. 625.

${ }^{30}$ Suhartono, 1991,op.cit., hlm. 117.
} 
tetap dilaksanakan. Pergeseran ke arah ekonomi uang tidak dapat dihindari. ${ }^{31}$ Menurut Houben, pada abad awal ke-19 sistem pajak dilakukan oleh anggota komunitas desa dalam bentuk produk pertanian, selanjutnya sepanjang abad tersebut pajak dibayarkan hanya dalam bentuk uang tunai. ${ }^{32}$ Sejak tahun 1837 , F.G. Valck mendefinisikan pajeg atau pajak sebagai "mengambil alih sebagian kecil hasil terbesar ladang atau sawah yang menjadi hak raja pemilik temporernya".

Proses monetisasidi Jawa Tengah diperkirakan telah berlangsung secara lama meskipun hanya secara parsial. Proses tersebut terjadi pada awal abad ke19, dibuktikan dengan mudahnya ditemukannya uang di tingkat pedesaan. Dalam periode sebelumnya, para pejabat Jawa sudah memiliki uang untuk dibelanjakan, sedangkan para bupati dan wedana telah membayar pajak kepada raja secara teratur dengan menyerahkan uang.

Kecenderungan ke arah ekonomi uang makin nyata setelah kerja wajib dapat dibayar menggunakan uang. Sebagai contoh adalah uang kerigaji pada tahun 1848 dan uang zegel (zegel gelden) pada tahun 1857. Sealin itu, proses penyewaan tanah oleh ondernemingkepada para petani juga telah dibayarkan dengan uang. Pada tahun 1910, perkebunan tembakau Gayamprit, Klaten membayar sewa tanah kepada petani sebesar f 45 per bau selama satu tahun. Adapun untuk penanaman tebu seperti di Gondangwinangun, petani menerima sewa tanah sebesar f 69 per bau untuk setiap musim tanam. Namun, dalam kenyataannya, petani yang menyewakan tanahnya untuk perusahaan perkebunan justru mengalami kerugian. Hal ini dikarenakan pendapatan selama menanam padi jauh lebih tinggi dibandingkan sistem sewa tanah yang diterimanya. Meskipun ditambah dengan upah kerja sebesar f 66 per bau, hasil menanam padi jauh lebih tinggi dibandingkan menyewakan tanah. ${ }^{33}$ Dapat dikatakan bahwa kehidupan ekonomi petani dianggap lebih buruk di tanah-tanah perkebunan. Selain itu, pemerintah menyerap kembali upah tanam dan upah kerja serta sewa tanah

${ }^{31}$ Ibid. hlm. 619.

${ }^{32}$ Houben, Vincent J.H, Op. Cit., (Yogyakarta: Bentang Pustaka, 2002), ${ }^{33}$ Suhartono, 1991, op.cit., hlm. 118. 
melalui pembayaran pajak, penjualan candu,garam serta barang-barang impor lainnya.

Secara eksplisit, keberadaan perusahaan asing telah mengubah sistem perekonomian masyarakat daerah di sekitar perkebunan. Dengan uang hasil upah kerja di perkebunan, tingkat konsumsi masyarakat juga senantiasa mengalami peningkatan. Uang yang diterima oleh para petani memiliki dampak luas karena uang tersebut digunakan untuk membeli barang-barang impor seperti kain dan barang kenikmatan seperti candu dan minuman keras. Hal tersebut menunjukkan, proses monetarisasitelah membawa dampak dalam kehidupan sosial masyarakat. Uang telah memiliki peranan penting dalam kehidupan masyarakat, khususnya bagi masyarakat sekitar daerah perusahaan perkebunan.

Dampak dari masuknya uang hingga tingkat pedesaan telah disadari olehberbagai pihak seperti gubernemen maupun swasta. Pada tahun 1917, H.A. Desentje super intenden dari N.V. Cultuur Mij di Jungkare, Klaten memberi bantuan f 600 kepada setiap kebekelan, dengan tujuan untuk melindungi petani dari penghisapan lintah darat. Pada tahun yang sama, di Karesidenan Surakarta juga didirikan Dinas Pegadaian (Pandhuisdienst), yaitu rumah gadai pemerintah yang melayani peminjaman uang dengan tanggungan barang. Bersamaan dengan proses monetisasi yang terjadi, di beberapa wilayah juga telah didirikan pasar yang semula hanya terdapat di daerah pusat-pusat administrasi. Pada tahun 1918, pasar-pasar yang terdapat di sekitar perusahaan perkebunan di Klaten seperti di Pedan, Pandansimping, Jatinom, dan Delanggu telah direnovasi.

\section{Kesimpulan}

Tahun 1870 merupakan terbukanya pintu perdagangan dunia bagi Hindiabelanda. Melalui Undang-undang Agraria yang mempermudah pemodal-pemodal swasta asing untuk menyewa tanah dan menanamkan modal usaha di perusahaan perkebunan. Perkebunan pada masa kolonial berkembang pesat di Hindia Belanda, terutama di Jawa dan Sumatera. Pemodal-pemodal partikelir menanam tanaman-tanaman yang laku di pasaran dunia, seperti tebu, tembakau, nila, indigo, dan kopi. 
Masuknya pemodal-pemodal swasta ini ke Hindia-Belanda tentunya berpengaruh bagi kehidupan masyarakat pribumi. Lahan-lahan pertanian yang sebelum maraknya perkebunan, mayoritas ditanami tanaman pangan, tetapi kemudian mereka harus merelakan tanahnya untuk disewakan kepada pemodalpemodal untuk ditanami tanaman-tanaman eksport. Selain berkurangnya lahan untuk menanam tanaman pangan, masyarakat pribumi juga bisa menikmati kemajuan teknologi transportasi dengan adanya perkebunan.

Perkembangan pesat perkebunan, khususnya tebu di afdeling Klaten, membawa dampak bagi dibukanya pabrik-pabrik gula untuk mengolah tebu menjadi gula. Tenaga kerja diperlukan untuk menjadi buruh perkebunan dan buruh pabrik gula. Keterlibatan pribumu dalam perkembangan industry di perusahaan, tentu juga membawa pengaruh terhadap peredaran uang yang semula tidak begitu banyak digunakan di masyarakat. Upah sebagai buruh perkebunan maupun buruh pabrik dibayar dengan uang. Inilah yang memperbesar adanya peredaran uang di kalangan pribumi.

Selain perubahan kehidupan ekonomi masyarakat pribumi, kehidupan sosial masyarakat juga mengalami perubahan. Peredaran uang menyebabkan pribumi, khususnya petani menjadi ketergantungan terhadap perusahaan, karena dari perusahaanlah mereka mendapatkan uang untuk memenuhi kehidupan seharihari. Ketika buruh-buruh perkebunan berada di antara waktu tanam dan panen, yang mana terdapat jeda 6-8 bulan, dan tidak banyak yang dikerjakan, sementara ketika tidak kerja mereka tidak mendapatkan uang, maka tidak sedikit yang melakukan tindakan-tindakan kriminal, sebagai kecu untuk mendapatkan uang. Keberadaan kecu ini tentu meresahkan masyarakat pribumi.

Selain kriminalitas sebagai salah satu dampak negatif dari adanya perkebunan, pembuatan sarana transportasi sebagai sarana pengangkutan hasil produksi jga membawa dampak positif bagi masyarakat. Kreta api sebagai sarana angkut yang efektif dan efisien untuk mengangkut hasil produksi perusahaan di Klaten ke pelabuhan Semarang untuk diekspor, pada perkembangannya tidak hanya sebagai angkutan barang, tetapi juga sebagai alat transportasi manusia. Masyarakat pribumi bisa dengan lebih mudah melakukan perjalanan 
menggunakan keretta api, meskipun ada kelas-kelas dalam penggunaan alat transportasi tersebut, yaitu kelas satu dan dua untuk orang-orang Eropa dan kelas tiga dan empat untuk masyarakat pribumi.

\section{Daftar Pustaka}

Boomgard, Peter, Anak Jajahan Belanda: Sejarrah Sosial dan Ekonomi Jawa 1795-1880, (Jakarta: Djambatan, 2004)

Geertz, Cliford, Agrcultural Involution: The Process of Ecological Change in Indoneia, (Barkeley: TP, 1966).

Kunto Wibisono, dkk, Kereta Malam, (Yogyakarta: Gong Grafis, 2015).

Mubyarto Daryanti, Gula:Kajian Sosial-Ekonomi, (Yogyakarta: Aditya Media, 1991).

Mubyarto, Tanah dan Tenaga Kerja Perkebunan: Kajian Sosial Ekonomi, (Yogyakarta: Aditya Media, 1992).

Sjafri Sairin, "Kiat Perburuhan pada Masa Kolonial: Kasus Perkebunan Sumatera Timur", dalam Perspektif Vol. 5 No. 1\&2, 1993.

Suhartono, Apanage dan Bekel: Perubahan Sosial di Pedesaan Surakarta 18301920(Yogyakarta: Tiara Wacana, 1991).

Suhartono, Bandit-Bandit Pedesaan di Jawa Studi Historis 1850-1942, (Yogyakarta: Aditya Media, 1995)

Vincent J.H. Houben, Keraton dan Kompeni: Surakarta dan Yogyakarta, 18301870, (Yogyakarta: Bentang, 2002).

Soegijanto Padmo, Landreform dan Gerakan Protes Petani Klaten 1959-1965, (Yogyakarta: Media Pressindo, 2000).

Soegijanto Padmo,"Ekonomi Perkebunan dan Keresahan di Pedesaan Sebuah Survai Awal", Seminar Revolusi Kepahlawanan dan Pembangunan Bangsa, Oleh Museum Benteng Yogyakarta, 16 November 1994.

Suhartono, "Kecu: Potret Peradaban Sosial di Vorstenlanden 1850-1900", Seminar Sejarah Lokal di Medan, oleh Departmene Pendidikan dan Kebuadayaan,Tanggal 17-20 September 1984 
Wasino, Kapitalisme Bumi Putra: Perubahan Masyarakat Mangkunegaran, (Yogyakarta: Lkis, 2008 